\title{
Verdict in French blood trial shames science
}

Paris. Two former French blood transfusion officials, Michel Garretta and Jean-Pierre Allain, were given prison sentences last week for supplying haemophiliacs with clotting factors that they knew were infected with human immunodeficiency virus (HIV) and that could have been made safe by a heating process already in use in the United States and elsewhere. Although France was not the last European country to introduce heatinactivated blood products, the court's ruling reinforces the fact that the risks of HIV infection through unheated products were known in 1985 when the decisions were made and were deliberately ignored for political and economic reasons.

The verdicts vindicate the persistent efforts of haemophiliac groups and shame the scientific community and health authorities, which failed to intervene despite adequate warning signs. At the same time, the trial did not address allegations that government officials delayed the approval of a US AIDS test for five months in 1985 so that a French test could be released first (see Nature 353, 197; 1991).

Garretta, former head of the National Blood Transfusion Centre, was sentenced to four years in prison and fined FF500,000 (US $\$ 100,000$ ), the maximum penalty, for "deception over the qualities of the blood products he sold". A warrant was issued for the arrest of Garretta, who is in Boston; his lawyers say he will return to face his sentence. Allain, former head of research at the transfusion centre now working in Cambridge, England, was sentenced to four years in prison (two suspended) on the same charge.

The sentences affirm that the centre avoided importing heat-inactivated clotting

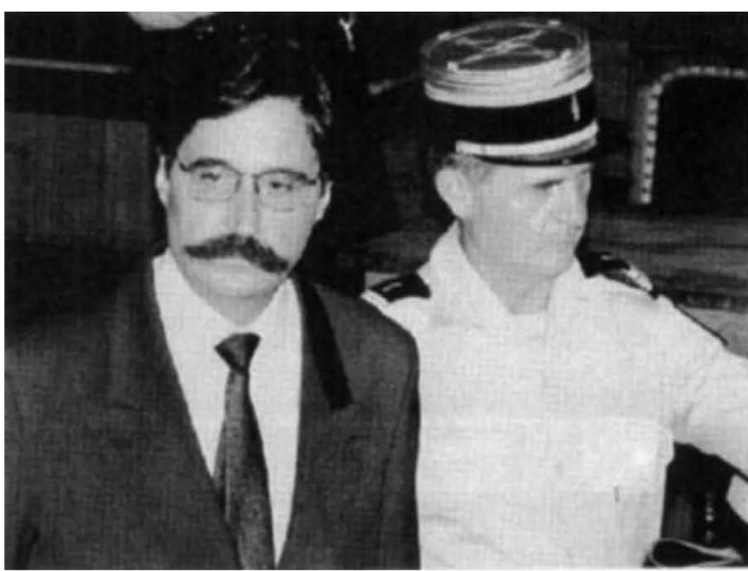

Garretta, shown during the trial, received a four-year prison sentence for allowing defective blood to be sold.

seven-month delay, which caused more than 1,500 haemophiliacs to be infected with $\mathrm{HIV}$; more than 250 have since died. Although the government had been unequivocally informed by 21 March 1985 that its blood products were contaminated with HIV, the products were not withdrawn until 20 October. Two government officials charged with "non-assistance to persons in danger" received lenient treatment: Jacques Roux, former director general of the Health Ministry, was given a four-year suspended sentence, and Robert Netter, former head of the National Health Laboratory, was acquitted.

Ministers in the Socialist government at the time (including Laurent Fabius, then prime minister and now leader of the Socialist party) testified in court that their scientific advisers had not adequately informed them of the risks posed by the tainted blood products. How much the government knew, and when it knew it, may never be known, but what is clear is that effective safeguards were lacking, and that public confidence in the

factors because France was waiting for the development of its own heat-activated products. Similarly, Garretta's decision to continue supplying contaminated products to haemophiliacs "until stocks are exhausted" seems to have been made on financial grounds.

While transfusion centre officials have been sentenced, the government has not been brought to account for its part in the

\section{NIH and Army meet on breast cancer windfall}

Washington. University researchers will benefit most from the $\$ 210$ million that the US Army has received for breast cancer research. The Army's decision to use the money for extramural, investigator-initiated projects approved through peer review by the National Institutes of Health (NIH) has reassured those concerned about its use but leaves unresolved NIH's role.

NIH and Army officials meeting last week to discuss the money awarded earlier this month in an amendment to the annual military appropriations bill (see Nature 359, 471 ; 1992) agreed to a task force of NIH researchers and Department of Defense (DOD) medical experts to suggest funding priorities. NIH officials are lobbying for basic research on such topics as potential environmental carcinogens and the role of chromosome 17, and would like at some point to include researchers and breastcancer advocacy groups. The research programme is expected to be set by February, with the money spent over two years.

The legislation ordered the military to cooperate with other federal agencies but did not specify to what degree. As a result, the Army is free either to hand over the entire project to NIH or to retain much of the responsibility for itself. It is not clear, for example, whether NIH will give the Army a list of projects to be funded and how much each should receive or whether it will simply submit a list of projects in order of scientific merit.

There is also concern that the Army will flood a few small areas with large amounts of money or select poorly from among competing fields of inquiry. For example, a project to develop digitized mammography machines is seen as an unwise use of some of the $\$ 25$ million it received last year to begin a breast cancer research programme.

Traci Watson scientific community and health authorities has been shattered.

Although uncertainties existed in 1985 as to the seriousness of HIV infection, it now seems clear that there were enough warning signs to have expected the scientific and medical community to have intervened. However, only a few individuals, among them Jacques Liebowitch of the Raymond Poincaré Hospital outside Paris and François Pinon of the Cochin Hospital in Paris, tried to alert officials to the dangers of the blood products.

The public has interpreted this silence as complicity, a suspicion that has been heightened by the perceived reluctance of the government, the judiciary and the scientific community to take up the haemophiliacs' cause. The persistent efforts of haemophiliac groups to raise the issue of whether contaminated blood products had been deliberately distributed has now been vindicated, while the scientific community has been portrayed as too ready to defend the status quo. Moreover, concern that a suit against the French transfusion service would harm morale and set a dangerous precedent for other European countries (see Nature 353, 781; 1991) now appears to be misplaced.

But the blood transfusion saga is unlikely to end with the verdicts on Garretta and Allain. They intend to appeal, the haemophiliacs have started proceedings to obtain a more far-reaching retrial and opposition parties in the government have called for a trial of the Socialist politicians in power at the time.

Declan Butler 